\title{
Electrowinning of Platinum Using a Modified Cyclone Reactor
}

\author{
Soo-Kyung KIM ${ }^{1,3}$, Churl Kyoung LEE ${ }^{2}$, \\ Jae-Chun LEE ${ }^{3}$, Kang-In RHEE ${ }^{3}$, \\ Hun-Joon SOHN ${ }^{1}$ and Tak KANG ${ }^{1}$
}

\author{
${ }^{1}$ School of Materials Science and Engineering, Seoul National University, Seoul, 151-742, Korea \\ ${ }^{2}$ School of Materials and Systems Engineering, Kumoh National Institute of Technology, \\ Gumi, Kyungbuk, 730-701, Korea \\ ${ }^{3}$ Minerals and Materials Processing Division, Korea Institute of Geoscience \& Mineral Resources, \\ Daejeon, 305-350, Korea
}

\begin{abstract}
The electrochemical behavior of platinum in dilute acidic media solutions were investigated using a rotating disc electrode system and a modified electrochemical cyclone cell at $25^{\circ} \mathrm{C}$. Electrochemical polarization data showed that the limiting current density for platinum deposition was observed around $-0.25 \mathrm{~V}$ (vs. SCE), and the diffusion coefficient of platinum estimated using Levich equation was $3.25 \times 10^{-6} \mathrm{~cm}^{2} \mathrm{~s}^{-1}$. The effects of several variables such as applied voltage, hydrochloric acid concentration and electrolyte flow rate were examined using a cyclone cell in order to obtain the optimum condition for electrowinning of platinum. More than $90 \%$ of the platinum in solution was recovered within an hour under the optimum conditions.
\end{abstract}

\section{Introduction}

Although platinum is extensively used as a catalyst in industrial chemical synthesis and in manufacture of electronic equipments, the distribution of platinum from the secondary sources in the environment has not been intensively studied and so far only little information is available [1,2]. With the introduction of platinum and platinum containing catalytic converters in the petrochemical industry, the emission of these metals into the environment has increased. Recently, as a technique for the recovery of platinum from secondary sources, hydrometallurgical processes using hydrochloric acid leaching have attracting increasing attention [3]. Since leaching solutions contain very small amounts of precious metal in general, enhancement of mass transfer by decreasing the diffusion layer thickness is very important to reduce the time and cost of electrowinning process. Based on the hydrocyclone's principal feature of

Accepted 6 February 2004 helical accelerated flow [4-7], an electrochemical cyclone cell was employed for the recovery of metal from dilute solution $[5,6]$, but the rate of removal of metal was still relatively low.

The aim of the present study is to investigate the electrochemical behavior of platinum in acidic chloride solution using a rotating disk electrode and also to find optimum conditions for platinum recovery using a modified electrochemical cyclone cell.

\section{Experimental}

A titanium disk of $1 \mathrm{~cm}^{2}$ was mounted in epoxy resin and polished with $3 \mu \mathrm{m}$ alumina powder for the rotating disk experiments. Electrolytes were prepared by dissolving $\mathrm{H}_{2} \mathrm{PtCl}_{6}$ (Aldrich, 99.99\%) in water and the $\mathrm{pH}$ was adjusted with hydrochloric acid. A typical three electrode system (titanium rotating disk electrode, vitreous carbon counter-electrode, and saturated calomel reference electrode) was employed to elucidate the basic electrochemical behavior of platinum in acidic solution, using EG \& G model 273 potentiostat/ 
galvanostat and a EG \& G rotator. All potentials are referred to the standard calomel electrode.

An electrochemical reactor, utilizing the principal features of the well-known hydrocyclone, was fabricated for platinum recovery in dilute acidic solution. The schematic arrangement of the cyclone-type cell is shown in Fig. 1(a). A similar cell was employed and tested previously, but the rate of recovery of metal was relatively slow $[5,6]$. The cell was modified, especially on the anode side to increase the anode area using a graphite tube as an anode. A titanium cylinder served as cathode, having an inner diameter of $25 \mathrm{~mm}$ and a height of $20 \mathrm{~mm}$. Electrolyte flowed not only through the apex at the bottom of the cyclone but also through the graphite tube (Fig. 1(b)) of which both the inner and outer sides can be served as an

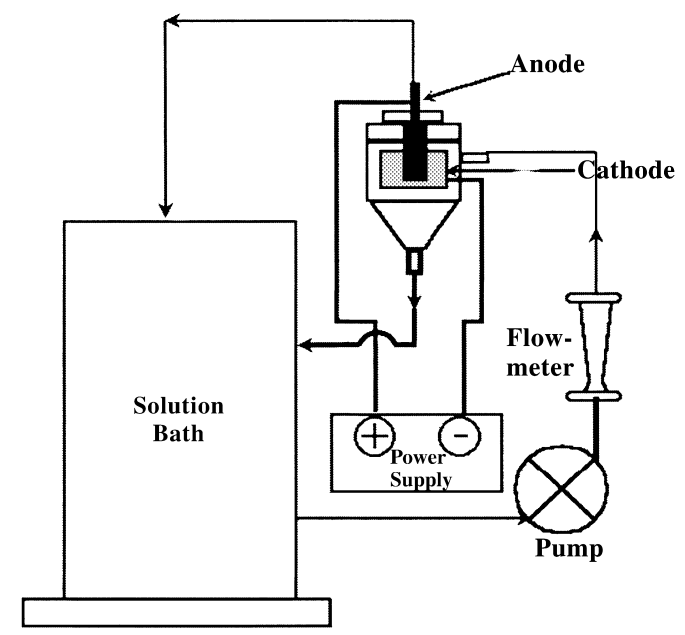

Fig. 1(a) Schematic of the electrochemical cyclone reactor; arrows indicate electrolyte.

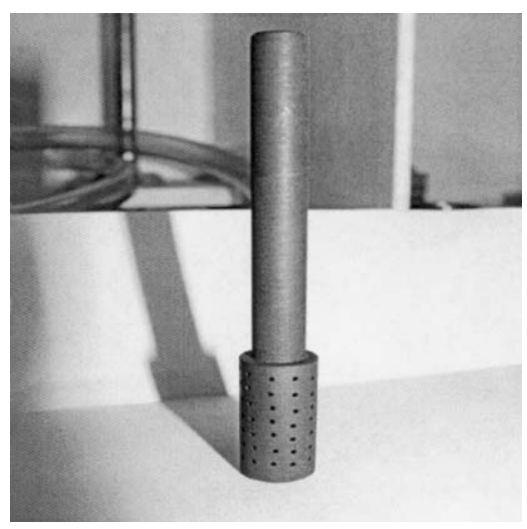

Fig. 1(b) The graphite tube. anode. These two electrodes were connected to a d.c. power supply. The solution-containing tank was coupled to the cell via a rotary pump to control the flow rate, and the flow rate of solution was measured with a flow-meter. All experiments were performed under potentiostatic conditions, and samples were withdrawn periodically to measure the $\mathrm{Pt}$ concentration by atomic absorption spectroscopy (GBC904 AA) or inductively coupled plasma spectroscopy (ICP-1000IV, Shimadzu).

\section{Results and discussion}

\section{Cathodic polarization behaviours}

Electrodeposition of platinum in acidic chloride media can be expressed as follows:

$$
\begin{array}{ll}
\begin{array}{l}
\text { Cathode } \\
\mathrm{PtCl}_{6}{ }^{2-}+4 \mathrm{e}^{-}=\mathrm{Pt}+6 \mathrm{Cl}^{-}
\end{array} & \mathrm{E}^{\mathrm{o}}=0.743 \mathrm{~V} \\
2 \mathrm{H}^{+}+2 \mathrm{e}^{-}=\mathrm{H}_{2} & \mathrm{E}^{\mathrm{o}}=-0.24 \mathrm{~V}
\end{array}
$$

Anode

$$
\begin{array}{ll}
\mathrm{H}_{2} \mathrm{O}=(1 / 2) \mathrm{O}_{2}+2 \mathrm{H}^{+}+2 \mathrm{e}^{-} & \mathrm{E}^{\mathrm{o}}=0.988 \mathrm{~V} \\
2 \mathrm{Cl}^{-}=\mathrm{Cl}_{2}+2 \mathrm{e}^{-} & \mathrm{E}^{\mathrm{o}}=1.117 \mathrm{~V}
\end{array}
$$

Where $\mathrm{E}^{\mathrm{o}}$ is the standard state potential.

Figure 2 shows the cathodic polarization curves with a variation of rotation speed at $25^{\circ} \mathrm{C}$. The limiting current density for platinum deposition was observed around $-0.25 \mathrm{~V}$ with a small potential range of $0.25 \mathrm{~V}$. In addition to, the limiting current density which appeared around $-0.50 \mathrm{~V}$ with a potential range of $0.50 \mathrm{~V}$ shows the hydro-

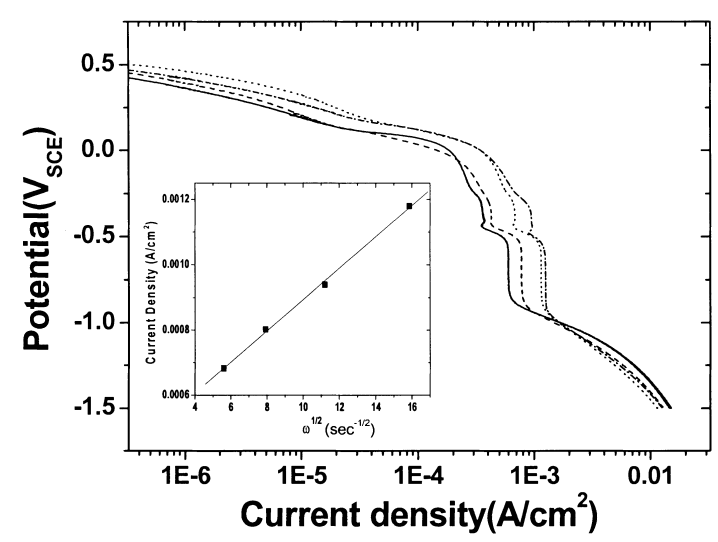

Fig. 2 Cathodic polarization curves with a variation of the rotating speed; $\mathrm{C}_{\mathrm{Pt}}=200 \mathrm{ppm}, \mathrm{pH}=3,25^{\circ} \mathrm{C}$, Key; (-) 300, (---) 600, (..) 1200 and (-.-) 2400 rpm. 
gen evolution and the cathodic polarization behavior was almost independent of $\mathrm{pH}$ as shown in Figure 3. Limiting current densities for platinum deposition are plotted against square root of rotation speed: the plot shows good linearity and obeys the Levich equation well [8],

$$
i_{1}=0.62 n F D^{2 / 3} v^{-1 / 6} \omega^{1 / 2} C_{\mathrm{b}}
$$

Here $i_{1}$ is the limiting current density, $n$ is the number of electrons transferred in Reaction $1, F$ is the Faraday constant, $D$ is the diffusivity, $v$ is the kinematic viscosity, $\omega$ is the electrode rotation speed, and $C_{\mathrm{b}}$ is the bulk concentration of platinum. The diffusion coefficient of platinum calculated from the slope of the inserted graph in Figure 2 is $3.25 \times 10^{-6} \mathrm{~cm}^{2} \mathrm{~s}^{-1}$, which agrees well with the reported value [9].

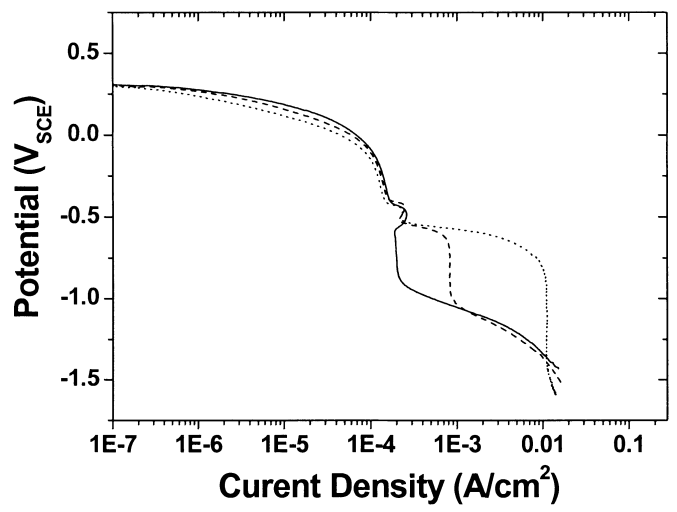

Fig. 3 Cathodic polarization curves with a variation of $\mathrm{pH} ; \mathrm{C}_{\mathrm{Pt}}=200 \mathrm{ppm}, 25^{\circ} \mathrm{C}, \omega=900 \mathrm{rpm}$. Key; (一) $\mathrm{pH}=2,(--) \mathrm{pH}=3$ and (...) $\mathrm{pH}=4$.

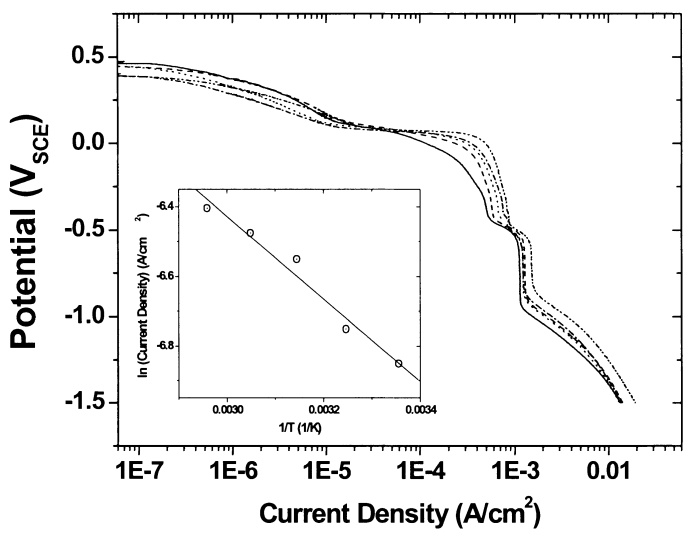

Fig. 4 Cathodic polarization curves with a variation of the solution temperature; $\mathrm{C}_{\mathrm{Pt}}=200 \mathrm{ppm}, \mathrm{pH}=3, \omega$ $=900 \mathrm{rpm}, \mathrm{Key} ;(-) 25,(--) 30,(\ldots) 40,(-\cdot-) 50$ and $(-\cdots) 60^{\circ} \mathrm{C}$.
Figure 4 illustrates the temperature dependency of the electrodeposition of platinum. An Arrhenius plot was made and the activation energy of $9.88 \mathrm{~kJ} \mathrm{~mol}^{-1}$ is obtained which supports that this system is diffusion controlled.

\section{Electowinning of Pt using a modified cyclone cell}

Electrowinning of platinum using a modified cyclone cell was performed at $25^{\circ} \mathrm{C}$. Figure 5 shows the effect of flow rate, which is correlated in terms of linear velocity of solution at an applied potential of $2 \mathrm{~V}$ and $\mathrm{pH}$ of 3 . Here the linear velocity is defined as the ratio of the flow rate to the cross sectional area of inlet in the cyclone cell. The concentration of platinum drops exponentially for high flow rates due to a turbulent nature, while linear-like shape appears for the laminar flow case of $0.6 \mathrm{~m} \mathrm{~s}^{-1}$, and the rate of removal of platinum from the solution increases with the flow rate.

The effect of applied voltage is shown in Figure 6 at a linear solution velocity of $3.0 \mathrm{~m} \mathrm{~s}^{-1}$ and $\mathrm{pH}$ of 3 . The initial concentration of platinum was approximately $200 \mathrm{ppm}$. In the case of $1.5 \mathrm{~V}$, the recovery of platinum is $75 \%$ after 2 hours while it reaches close to $90 \%$ at $2.0 \mathrm{~V}$ and $3.0 \mathrm{~V}$ within an hour. Comparing the latter two cases, the rates of recovery of platinum are close with each other, and this suggests that the current for recovery of platinum reaches the limiting current at $2.0 \mathrm{~V}$. Thus electrowinning at cell voltage of 2.0 $\mathrm{V}$ is more efficient than that of $3.0 \mathrm{~V}$. From a recovery rate point of view, the rate of recovery of platinum is slower than that of palladium [10].

From these results, the optimum applied voltage would be $2 \mathrm{~V}$ considering the energy consumption since the recovery rate of platinum would be slow at lower concentration of platinum.

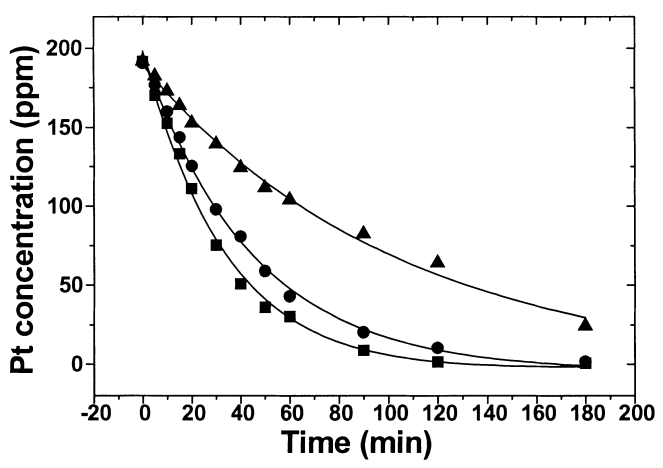

Fig. 5 Effect of flow rate on the recovery of the platinum; $\mathrm{C}_{\mathrm{Pt}_{\mathrm{t}}}=200 \mathrm{ppm}$, applied voltage $=2 \mathrm{~V}, \mathrm{pH}=3$, $25^{\circ} \mathrm{C}$. Key; $(\boldsymbol{\Delta}) 0.6,(\mathbf{O}) 1.8$ and (口) $3.0 \mathrm{~m} \mathrm{~s}^{-1}$. 


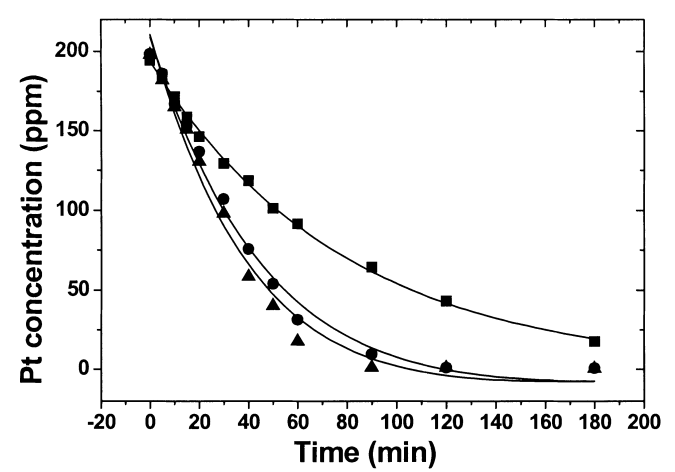

Fig. 6 Effect of applied voltage on the recovery of the platinum; $\mathrm{C}_{\mathrm{Pt}}=200 \mathrm{ppm}$, linear solution velocity $=$ $3 \mathrm{~m} \mathrm{~s}^{-1}, \mathrm{pH}=3,25^{\circ} \mathrm{C}$. Key; (ם) 1.5 , (O) 2.0 and (A) $3.0 \mathrm{~V}$.

At a relatively high cell voltage, the deposits are powdery and gray in color. However under the condition of cell voltage of lower than $1.5 \mathrm{~V}$, metallic films are obtained. In general, the increase of flow rate leads to a higher mass transfer but the erosion of the metal deposit takes place, and powdery deposits are observed similar to this study $[11,12]$.

\section{Conclusion}

The electrochemical behavior of platinum was investigated using a rotating disk electrode, and the electrowinning of platinum was carried out using a modified cyclone reactor in dilute acidic chloride solution. The diffusion coefficient and activation energy were obtained from rotating disk electrode experiments and found to be $3.25 \times$ $10^{-6} \mathrm{~cm}^{2} \mathrm{~s}^{-1}$ and $9.88 \mathrm{~kJ} \mathrm{~mol}^{-1}$, respectively. The optimum applied voltage of cyclone cell would be $2 \mathrm{~V}$ considering the energy consumption. Increasing the electrolyte flow promoted the rate of re- moval of platinum from the solution significantly, and $90 \%$ of platinum in solution was recovered within an hour under optimum condition. Finally, the electrowinning of platinum using a modified cyclone reactor is a prospective process for precious metal recovery from dilute solution efficiently.

\section{References}

1. R. Eller, F. Alt, G. Tolg, H.J. Tobschalt, Fresenius Z, Anal. Chem., 334 (1989), 723

2. V. Hodge, M. Stallard, Environ. Sci. Technol., 20 (1986), 1058

3. J.E. Hoffmann, J. Metals, 40 (1998) June, 40

4. L. Svarovsky and M.T. Thew, Hydrocyclones, Analysis and Applications, Kluwer Academic Publishers, 1992

5. N. Dhamo, J. Appl. Electrochem. 24 (1994), 745

6. N. Dhamo and R. Kammel, Metallwissenschaft und Technik 46 (1992), 912

7. K-I Rhee, J-C Lee, C-K Lee, K-H Joo, J-K Yoon, H-R Kang, Y-S Kim and H-J Sohn, Recycling of Metals and Engineered Materials, Proceedings of the Third International Symposium, TMS, Point Clear, Alabama November 12-15, 1995,

8. V.J. Levich, 'Physicochemical Hydrodynamics' (Prentice-Hall, 1962)

9. A.J. Bard, 'Encyclopedia of Electrochemistry of the Elements' Vol. 6 (Marcel Dekker, New York, 1976)

10. Y-U. Kim, H-W. Cho, H-S. Lee, C-K. Lee, JC. Lee, K-I. Rhee, H-J. Sohn and T. Kang, J. Appl. Electrochem., 32 (2002) 1235

11. J. Legrand, J.M. Marracino and F. Coeuret, J. Appl. Electrochem., 16 (1986) 365

12. T. Sasaki and T. Ishikawa, Electrochim. Acta, 31 (1986) 745 